\title{
Aplikasi edible film maizena dengan penambahan ekstrak jahe sebagai antioksidan alami pada coating sosis sapi
}

\author{
The application of maizena-edible film with the addition of ginger extract as a natural \\ antioxidant in cow sausage coating
}

\author{
HENY RATRI ESTININGTYAS, KAWIJI, GODRAS JATI MANUHARA \\ Prodi Teknologi Hasil Pertanian, Fakultas Pertanian, Universitas Sebelas Maret, Jl. Ir. Sutami 36a Surakarta 57126, Jawa Tengah
}

Manuscript received: 6 September 2011. Revision accepted: 26 Desember 2011.

\begin{abstract}
Estiningtyas HR, Kawiji, Manuhara GJ. 2012. The application of maizena-edible film with the addition of ginger extract as a natural antioxidant in cow sausage coating. Biofarmasi 10: 7-16. The addition of ginger extract containing natural antioxidants into the edible coating of sausage is expected to reduce the oxidative deterioration of lipids in sausage. The objectives of this study were to determine the concentration of ginger extract addition to edible coating sausage, to determine the effect of ginger extract added to the edible coating on the level of lipid damage in sausage during storage, and to determine the physical and mechanical characteristics of the edible film which most preferred by panelists compared with control. This study consisted of five main stages, i.e., the preparation of ginger extract, making edible film solution, the application of edible film, the edible film application as sausage coating, and the characterization of edible film. This study used a complete randomized design with two replications of making an edible film for each treatment of ginger extract concentration and two replications of the characteristic test of edible film. The obtained data were analyzed for variants; if there was a difference, it continued to be analyzed with Duncan's Multiple Range Test at 0.05 of the significance level. Based on the test results conducted on the application of edible coating sausage (organoleptic test, loss weight test, and lipid oxidation test), it was determined that the best treatment was the addition of $10 \%$ ginger extract on edible coating sausage. The edible film with $10 \%$ ginger extract addition was selected for the physical and mechanical characteristics test. When compared with control (without the addition of ginger extract), the results showed no significant difference for all parameters except the solubility test. The solubility of the edible film with the addition of ginger extract was higher than the control.
\end{abstract}

Keywords: Antioxidant, edible film, maizena

\section{PENDAHULUAN}

Penggunaan plastik sebagai pengemas sudah tidak dapat dihindari dalam kehidupan sehari-hari, termasuk sebagai kemasan makanan. Hal ini terjadi karena plastik merupakan bahan pembungkus makanan yang murah, mudah didapat, dan tahan lama. Akan tetapi, zat-zat adiktif dalam plastik mudah terurai dalam lemak dan panas, sehingga apabila mengkontaminasi makanan yang masuk ke dalam tubuh, secara akumulatif pada hewan percobaan dapat mengakibatkan penyakit kanker, perubahan hormon, dan menyebabkan kelahiran berjenis kelamin ganda.

Sebagai pengganti plastik sintetik, telah dikembangkan plastik biodegradable. Plastik biodegradable merupakan jenis plastik yang dapat hancur dan terurai oleh aktivitas mikroorganisme setelah terpakai dan dibuang ke lingkungan (Riadi 2007). Terdapat jenis biodegradable film yang dapat dimakan (edible), yang sering disebut dengan edible film.

Edible film merupakan lapisan tipis yang umumnya digunakan untuk melapisi makanan (coating), atau diletakkan di antara komponen-komponen yang berfungsi sebagai penahan terhadap transfer massa, seperti air, oksigen, dan lemak, atau dimanfaatkan sebagai pembawa bahan pangan tambahan. Dalam berbagai kasus, edible film dengan sifat mekanik yang baik dapat menggantikan pengemas sintetik (Krochta dan de Mulder-Johnston 1997). Edible film dapat dibuat dari maizena. Maizena mengandung zein. Salah satu karakteristik yang menarik dari zein adalah kemampuannya untuk membentuk film yang kaku, mengilap, tahan lecet, dan tahan lemak (Pomes 1971).

Salah satu fungsi edible film tersebut dapat diaplikasikan pada produk sosis. Sosis merupakan salah satu produk olahan daging yang sangat digemari masyarakat Indonesia sejak tahun 1980-an (Astawan 2008). Tidak hanya disukai orang tua, tetapi sosis juga disukai orang dewasa dan anak-anak, karena selain rasanya yang lezat, makanan tersebut juga tergolong mudah disajikan. Sosis dapat dimakan sebagai makanan ringan (snack). Makanan berbentuk bulat panjang dan berwarna merah atau cokelat tersebut umumnya terbuat dari daging, diantaranya daging ayam, sapi, domba, ikan, atau babi. Setelah diolah, daging dibungkus dengan bungkus buatan atau usus hewan (Suratmo 2008). Sosis mengandung lemak yang berbeda-beda dan kolesterol cukup tinggi (50-100 $\mathrm{mg} / 100 \mathrm{~g}$ ), sehingga sangat mudah mengalami kerusakan, terutama kerusakan lemak akibat oksidasi.

Lemak hewan banyak mengandung asam lemak tidak jenuh, seperti asam oleat (18:1) sebesar 12,01\%, asam 
palmitoleat $(16: 1)$ sebesar 1,38\%, asam linoleat (18:2) sebesar 1,99\%, dan asam linolenat (18:3) sebesar 0,41\%. Asam lemak tersebut dapat mengalami oksidasi, sehingga menimbulkan bau tengik pada daging. Hasil penguraian dan oksidasi pada ikatan rangkap dari asam lemak tidak jenuh adalah asam lemak bebas, yang merupakan sumber bau tengik. Kecepatan oksidasi berbanding lurus dengan tingkat ketidakjenuhan asam lemak. Asam linolenat dengan tiga ikatan rangkap akan lebih mudah teroksidasi daripada asam lemak linoleat dengan dua ikatan rangkap dan asam lemak oleat dengan satu ikatan rangkap. Ketidakjenuhan lemak dalam daging yang digunakan untuk membuat sosis memungkinkan sosis mengalami oksidasi.

Coating sosis menggunakan edible film dapat diperkaya dengan penambahan antioksidan jahe untuk menurunkan potensi oksidasi lemak pada sosis. Jahe (Zingiber officinale) memiliki kandungan fenol seperti 6-gingerol dan 6-shogaol yang dapat berfungsi sebagi antioksidan (Nakatani 1992).

Gingerol dan shogaol mampu berperan sebagai antioksidan primer terhadap radikal lipid. Gingerol dan shogaol mempunyai aktivitas antioksidan karena mengandung cincin benzena yang mengandung gugus hidroksil. Mekanisme reaksi antioksidan senyawa fenolik terjadi melalui pemberian atom hidrogen dari gugus hidroksil kepada senyawa radikal, sedangkan turunan radikal antioksidan yang terbentuk cukup stabil atau secara sterik dicegah dari reaksi berikutnya, sehingga radikal antioksidan tidak akan bekerja sebagai suatu inisiator bagi reaksi berikutnya (Zakaria 2000).

Antioksidan ditambahkan pada edible coating untuk meningkatkan stabilitas dan mempertahankan nutrisi produk pangan dengan melindungi produk dari ketengikan oksidatif, degradasi, dan diskolorasi. Terdapat dua jenis antioksidan dalam pangan, yaitu asam dan senyawa fenolik (Sherwin 1990). Penambahan senyawa fenolik pada edible film juga pernah dilakukan oleh Guilbert (1988), yaitu dengan menambahkan $\alpha$ - tokoferol pada film dari gelatin.

Aplikasi edible film dari maizena yang ditambah dengan ekstrak jahe yang mengandung antioksidan alami pada coating sosis dalam penelitian ini dilakukan untuk mengetahui tingkat kerusakan lemak pada sosis, mengetahui tingkat kesukaan konsumen, dan mengetahui sifat mekanik dan fisik dari edible film yang paling disukai konsumen. Adapun pengujian yang dilakukan adalah uji kerusakan lemak (TBA dan kandungan ALB), uji susut berat, pengujian secara organoleptik, dan uji sifat fisik (kelarutan, ketebalan film, dan WVP), serta sifat mekanik (pemanjangan film [elongasi], kekuatan regang putus [tensile strength]).

Tujuan dari penelitian ini adalah untuk mengetahui konsentrasi penambahan ekstrak jahe pada edible coating sosis yang paling disukai oleh panelis, mengetahui pengaruh penambahan ekstrak jahe pada edible coating sosis terhadap tingkat kerusakan lemak sosis selama penyimpanan, serta mengetahui karakteristik fisik dan mekanik edible film yang paling disukai oleh panelis dibandingkan dengan kontrol.

\section{BAHAN DAN METODE}

\section{Waktu dan tempat penelitian}

Penelitian ini dilaksanakan di Laboratorium Rekayasa Proses Pengolahan Pangan dan Hasil Pertanian, Laboratorium Pangan dan Gizi, Jurusan Teknologi Hasil Pertanian, Fakultas Pertanian, Universitas Sebelas Maret Surakarta, Laboratorium TPHP UGM Yogyakarta, dan Laboratorium CV. Chemix Pratama Yogyakarta.

\section{Alat dan bahan}

Alat yang digunakan untuk membuat edible film yaitu gelas ukur, pelat plastik, hotplate, pengaduk, magnetic stirrer, beaker glass, dan oven. Alat yang digunakan untuk karakterisasi edible film yaitu micrometer Mitutoyo (ketelitian 0,001), Lloyd's Universal Testing Instrument 50 $\mathrm{Hz}$ model $1000 \mathrm{~s}$, stoples plastik, dan cawan WVP. Alat yang digunakan untuk analisis nilai susut berat yaitu cawan WVP, stoples, silica gel, dan timbangan analitik. Alat untuk uji kerusakan lemak yaitu serangkaian alat destilasi, serangkaian alat titrasi, serta spektrofotometer.

Sementara itu, bahan yang digunakan untuk pembuatan edible film meliputi maizena merek "Maizenaku“, ekstrak jahe emprit yang diperoleh dari pasar Legi Surakarta, akuades, gliserol, dan $\mathrm{Ca}(\mathrm{OH})_{2}$. Bahan yang digunakan untuk tahap aplikasi yaitu sosis sapi merek "Bernaddi" yang diperoleh dari Hypermart. Bahan yang digunakan untuk karakterisasi dan aplikasi edible film meliputi akuades, sosis, silica gel, standar TBA, TCA, etanol, $\mathrm{NaOH} 0,1 \mathrm{~N}$, dan asam asetat glasial.

\section{Rancangan percobaan}

Dalam penelitian ini digunakan Rancangan Acak Lengkap dengan dua kali ulangan pembuatan edible film untuk setiap perlakuan konsentrasi ekstrak jahe.

\section{Cara kerja}

Penyiapan bahan

Ekstraksi jahe dilakukan berdasarkan metode yang digunakan oleh Hasyim (2008), yaitu rimpang jahe dibersihkan dan dicuci. Kemudian, jahe diiris tipis untuk mempercepat proses pengeringan dalam kabinet dryer pada suhu $60^{\circ} \mathrm{C}$ selama 6 jam. Setelah kering, irisan-irisan jahe diblender menggunakan blender kering, selanjutnya diseragamkan ukurannya dengan pengayakan ukuran 40 mesh. Serbuk jahe ditambah dengan air panas dengan rasio serbuk jahe dan air sebesar 1:10 (b/v). Hasilnya kemudian disaring, sehingga diperoleh ekstrak jahe. Selanjutnya, ekstrak jahe yang diperoleh digunakan dalam pembuatan edible film dengan variasi konsentrasi $0 \%, 10 \%, 20 \%$, dan $30 \%(\mathrm{v} / \mathrm{v})$.

\section{Pembuatan edible film berantioksidan untuk aplikasi pada coating sosis}

Pembuatan edible film berantioksidan mengacu pada metode yang dikembangkan oleh Manuhara (2003) yang dimodifikasi dengan metode pembuatan gel glukomanan yang disarankan oleh Phillips dan Williams (2000) serta Aminah (1992). 
Mula-mula, tiga jenis larutan disiapkan terlebih dahulu. Larutan pertama berupa larutan ekstrak jahe. Akuades yang digunakan dalam pembuatan edible film adalah akuades yang diperkaya dengan ekstrak jahe. Larutan ekstrak jahe dibuat dari serbuk jahe kering yang dilarutkan ke dalam akuades panas kemudian disaring dengan perbandingan serbuk jahe dan air yaitu 1:10 (b/v). Selanjutnya dibuat konsentrasi larutan ekstrak jahe $0 \%$ (v/v akuades), $10 \%$ (v/v akuades), $20 \%$ (v/v akuades), dan $30 \%$ (v/v akuades). Jumlah akuades total yang digunakan dalam pembuatan edible film yaitu $300 \mathrm{~mL}$.

Larutan kedua yang digunakan yaitu larutan maizena. Mula-mula maizena ditambah dengan akuades sebanyak $150 \mathrm{~mL}$ dan dipanaskan sampai terjadi gelatinisasi.

Larutan ketiga berupa gliselol dan $\mathrm{Ca}(\mathrm{OH})_{2}$ sebesar $0,00156 \mathrm{~g}$ yang dilarutkan dalam akuades dengan variasi $120 \mathrm{~mL}, 90 \mathrm{~mL}$, dan $60 \mathrm{~mL}$, kemudian dipanaskan dan diaduk sampai larut.

Ketiganya jenis larutan tersebut selanjutnya dicampur dan dipanaskan di atas hotplate selama 30 menit, dan dilanjutkan dengan pengadukan menggunakan magnetic stirrer. Pemanasan dan pengadukan dilakukan sampai semua bahan larut. Setelah suhu larutan turun, sosis dicelupkan ke dalam larutan tersebut.

\section{Aplikasi edible film}

Pengujian ini ditentukan dengan cara coating pada sosis, kemudian dilakukan uji susut berat, uji organoleptik, dan tingkat kerusakan lemak. Aplikasi film dengan cara coating (pelapisan) pada daging sosis mengacu pada metode yang digunakan MgHugh dan Sanesi (2000) yang telah dimodifikasi. Sosis dicelupkan ke larutan edible film selama 5 menit. Sosis dipindahkan dari larutan dan dikeringkan pada suhu $40^{\circ} \mathrm{C}$ selama 35 menit dengan hair driyer. Pencelupan dilakukan selama dua kali agar semua bagian sosis terlapisi secara merata.

Dari hasil analisis yang dilakukan pada tahap aplikasi, diperoleh konsentrasi ekstrak jahe yang paling optimal dan paling disukai oleh panelis, sehingga untuk selanjutnya dilakukan pengujian pada karakteristik fisik dan mekanik pada edible film tersebut.

\section{Karakterisasi edible film}

Pengujian karakteristik edible film dilakukan pada edible film terpilih yang paling disukai oleh panelis. Pengujian karakter fisik dan mekanik pada edible film meliputi ketebalan film (MgHugh dan Krochta 1994), pemanjangan film, kuat regang putus film, kelarutan film, dan permeabilitas uap air (WVP) (Gontard et al. 1993).

\section{Analisis data}

Data yang didapat selanjutnya dianalisis varian. Jika terdapat perbedaan maka dilanjutkan dengan uji beda nyata menggunakan analisis Duncan Multiple Range Test pada tingkat signifikansi 0,05 .

\section{HASIL DAN PEMBAHASAN}

Terdapat banyak bahan yang digunakan sebagai pengemas makanan, yaitu kemasan yang bersentuhan langsung dengan makanan, salah satunya yaitu edible film. Edible film adalah lapisan tipis yang terbuat dari bahanbahan yang dapat dimakan, digunakan untuk melapisi komponen makanan (coating) atau diletakkan di antara komponen makanan (film) yang berfungsi sebagai barrier terhadap transfer massa (misalnya kelembapan, oksigen, lipid, cahaya, dan zat terlarut), dan/atau sebagai carrier bahan makanan dan bahan tambahan, serta untuk mempermudah penanganan makanan (Krochta dan de Mulder-Johnson 1997).

Pada penelitian ini, edible film dibuat dari maizena dan diperkaya dengan ekstrak jahe yang mengandung antioksidan alami. Edible film tersebut kemudian diaplikasikan pada coating sosis dan dilakukan beberapa pengujian.

\section{Aplikasi edible film maizena dengan penambahan ekstrak jahe}

Pengujian dalam aplikasi ini meliputi uji organoleptik yang diujikan kepada 20 panelis, uji kerusakan lemak yaitu uji TBA dan uji asam lemak bebas, serta uji susut berat. Pengujian ini dilakukan untuk memperoleh edible film terbaik dengan tingkat kerusakan lemak dan susut berat terkecil, serta disukai oleh panelis.

\section{Uji organoleptik}

Dalam perancangan produk baru, pengujian dengan indrawi sangat berperan. Bentuk pengujian indrawi tersebut paling mendasar dan pertama kali dilakukan oleh perancang yang bekerja pada pengembangan suatu produk baru (Larmond 1977). Sifat organoleptik sangat penting bagi setiap produk, karena berkaitan erat dengan penerimaan konsumen. Untuk mengetahui tingkat penerimaan panelis terhadap konsentrasi ekstrak jahe yang ditambahkan pada edible coating sosis maka digunakan uji kesukaan (Hedonic Test). Pengujian organoleptik dengan uji kesukaan tersebut dilakukan dengan melibatkan indra pembau, perasa, penglihatan, dan peraba pada sampel dengan 5 parameter berdasarkan tingkat kesukaan panelis.

Edible film maizena yang diperkaya dengan antioksidan alami ekstrak jahe diaplikasikan pada coating produk sosis sapi yang dijual di pasaran. Pada Tabel 1 disajikan skor hasil pengujian organoleptik yang dilakukan oleh 20 orang panelis dengan 5 parameter uji, yaitu aroma, rasa, aftertaste, tingkat kekenyalan, dan keseluruhan berdasarkan uji kesukaan.

\section{Aroma}

Bau atau aroma dapat didefinisikan sebagai sifat-sifat bahan makanan yang memberikan kesan pada sistem pernapasan, atau dengan kata lain aroma merupakan sifatsifat produk yang dirasakan oleh indra penciuman (Darmaji 2002). Aroma merupakan salah satu faktor pendukung cita rasa yang menentukan kualitas suatu produk. Aroma juga merupakan salah satu indikator untuk menentukan tingkat penerimaan suatu produk oleh konsumen. Menurut de Man 
(1989), pengujian aroma pada suatu produk baru dianggap penting karena cepat memberikan hasil penilaian terhadap produk tersebut terkait diterima atau tidaknya suatu produk.

Pengujian aroma dilakukan untuk mengetahui tingkat kesukaan panelis terhadap sampel dengan peningkatan konsentrasi ekstrak jahe pada edible coating sosis. Semakin tinggi konsentrasi ekstrak jahe yang digunakan maka semakin tinggi intensitas aroma jahe yang terdeteksi oleh indra penciuman panelis. Namun, dari Tabel 1 dapat diketahui bahwa peningkatan konsentrasi ekstrak jahe tidak menunjukkan hasil yang berbeda nyata pada keempat sampel dengan konsentrasi ekstrak jahe yang berbeda-beda. Skor nilai 3 menunjukkan bahwa panelis memiliki tingkat kesukaan yang netral terhadap sampel dengan penambahan ekstrak jahe 10\%, 20\%, dan 30\%. Adapun untuk sampel dengan penambahan ekstrak jahe $0 \%$, panelis memberikan skor 4 yang berarti suka. Dengan demikian, penambahan ekstrak jahe pada edible coating sosis cenderung menurunkan tingkat kesukaan panelis terhadap aroma, namun tidak menunjukkan perbedaan yang nyata dengan edible coating sosis tanpa ekstrak jahe.

Pada dasarnya, luasnya penggunaan jahe disebabkan karena aromanya yang khas dan dapat diterima oleh konsumen (Ardiansyah 2007). Aroma khas jahe pada penelitian ini pun masih tetap dapat diterima oleh konsumen dengan penilaian yang berbeda-beda.

\section{Rasa}

Rasa terbentuk dari sensasi yang berasal dari perpaduan antara bahan pembentuk dan komposisinya pada suatu produk makanan yang ditangkap oleh indra pengecap, serta merupakan salah satu pendukung cita rasa yang mendukung kualitas suatu produk. Cita rasa sendiri didefinisikan oleh Hall (1968) dalam de Man (1976) sebagai rangsangan yang ditimbulkan oleh bahan yang dikonsumsi, terutama dirasakan oleh indra pengecap dan pembau, serta rangsangan lain seperti perabaan dan penerimaan derajat panas di mulut.

Dari hasil analisis data statistik pada Tabel 1, untuk parameter rasa juga tidak menunjukkan adanya beda nyata antar sampel dengan penambahan ekstrak jahe 0\%, 10\%, $20 \%$, maupun $30 \%$. Dengan demikian, peningkatan konsentrasi penambahan jahe pada edible film pada coating sosis tidak berpengaruh secara signifikan terhadap parameter rasa. Pada umumnya, jahe memiliki rasa yang khas yaitu pedas, yang ditimbulkan oleh kandungan jahe yaitu resin non-volatil yang mengandung komponen hydroxyaryl. Akan tetapi pada aplikasi ini, rasa pedas pada jahe masih tetap dapat diterima oleh panelis dengan kisaran penilaian netral sampai dengan suka.

\section{Aftertaste}

Aftertaste adalah sensasi rasa yang tertinggal setelah suatu produk dikonsumsi. Indra yang berperan yaitu indra pengecap dan indra pembau. Aftertaste yang dirasakan setelah mengonsumsi sampel sosis yang telah diberi perlakuan coating dengan penambahan ekstrak jahe adalah adanya sedikit rasa pahit.

Jika dibandingkan dengan kontrol (tanpa penambahan ekstrak jahe), penambahan ekstrak jahe sebesar 20\% dan
$30 \%$ secara nyata menurunkan tingkat kesukaan panelis. Adapun penambahan ekstrak jahe $10 \%$ sedikit menurunkan tingkat kesukaan panelis, tetapi tidak berbeda nyata dengan kontrol. Skor nilai yang diberikan pada sampel dengan penambahan ekstrak jahe $20 \%$ dan $30 \%$ masing-masing sebesar 2,85 dan 2,95 yang berarti kurang suka. Adapun skor nilai yang diberikan pada sampel dengan penambahan ekstrak jahe $0 \%$ dan $10 \%$ masing-masing sebesar 3,40 dan 3,75 yang berarti suka.

Aftertaste pahit yang timbul diduga akibat adanya kandungan resin di dalam jahe. Paimin et al. (1991) menyatakan bahwa jahe mengandung komponen minyak menguap (volatile oil), minyak tidak menguap (nonvolatile oil), dan pati. Minyak menguap yang biasa disebut minyak atsiri merupakan komponen pemberi bau yang khas, sedangkan minyak tidak menguap yang biasa disebut oleoresin merupakan komponen pemberi rasa pedas dan pahit.

\section{Kekenyalan}

Edible film umumnya diaplikasikan pada makanan dengan cara pembungkusan, pencelupan, penyikatan, atau penyemprotan. Teknik pencelupan biasanya digunakan pada produk daging, ikan, produk ternak, buah, dan sayuran. Pengujian terhadap parameter kekenyalan dilakukan untuk mengetahui apakah pencelupan sosis dalam larutan edible film mempengaruhi tingkat kekenyalan sosis.

Di dalam larutan edible film, terbentuk matriks gel yang dapat masuk ke dalam jaringan sosis dan mempengaruhi kekenyalan sosis. Pada Tabel 1 dapat dilihat bahwa pada parameter kekenyalan tidak menunjukkan adanya beda nyata di antara keempat sampel. Dengan demikian, coating sosis dengan metode pencelupan pada larutan film ternyata tidak mempengaruhi kekenyalan sosis. Skor nilai 3 yang diberikan pada sampel menunjukkan penerimaan panelis terhadap sampel dengan kategori disukai.

\section{Keseluruhan}

Kesukaan dan penerimaan konsumen terhadap suatu produk tidak hanya dipengaruhi oleh satu faktor, akan tetapi juga dapat dipengaruhi oleh berbagai macam faktor, sehingga menimbulkan penerimaan yang utuh. Tujuan dari pengujian ini adalah panelis diminta untuk menilai tingkat kesukaannya terhadap sampel sosis yang telah di-coating menggunakan edible film dengan penambahan ekstrak jahe yang mengandung antioksidan alami pada berbagai konsentrasi.

Dari data pada Tabel 1 dapat diketahui bahwa antara sampel dengan penambahan ekstrak jahe $0 \%$ dan 10\%, tidak berbeda nyata, tetapi keduanya berbeda nyata dengan sampel dengan penambahan ekstrak jahe $20 \%$ dan $30 \%$. Untuk sampel dengan penambahan ekstrak jahe $0 \%$ dan $10 \%$ cenderung disukai, sedangkan untuk sampel $20 \%$ dan $30 \%$ cenderung netral. Dengan demikian, peningkatan konsentrasi ekstrak jahe cenderung menurunkan tingkat kesukaan panelis terhadap parameter keseluruhan. Penurunan tingkat kesukaan panelis tersebut diduga terjadi akibat pengaruh aftertaste yang ditimbulkan oleh ekstrak jahe yang ditambahkan. 


\section{Uji susut berat}

Salah satu fungsi edible film adalah untuk menahan migrasi uap. Kehilangan uap air pada produk sosis menyebabkan produk menjadi keras dan kisut. Kecepatan susut berat menunjukkan kemampuan film untuk melindungi produk yang dikemas dari migrasi senyawasenyawa yang terdapat dalam bahan, sehingga bahan tetap terjaga kualitasnya. Semakin kecil kecepatan susut berat suatu produk maka kemasannya semakin baik.

Edible film maizena dengan empat formulasi penambahan ekstrak jahe telah diaplikasikan pada sosis. Sebagai kontrol, digunakan edible film maizena tanpa penambahan ekstrak jahe. Sosis yang telah dicelupkan ke dalam larutan edible film kemudian diletakkan pada cawan dan dimasukkan ke dalam stoples tertutup yang berisi silica gel. Stoples kemudian disimpan di dalam lemari pendingin bersuhu $10^{\circ} \mathrm{C}$ selama 8 hari.

Metode coating untuk aplikasi edible film dilakukan selama 8 hari dengan penimbangan berat cawan setiap harinya. Parameter yang diamati pada tahap aplikasi ini adalah susut berat selama 8 hari penyimpanan.

Hasil pengujian susut berat sosis yang di-coating dengan edible film maizena dengan penambahan ekstrak jahe sebagai antioksidan alami dapat dilihat pada Gambar 1, dimana edible film maizena memiliki susut berat sedikit lebih tinggi daripada edible film kontrol selama penyimpanan. Akan tetapi, hasilnya tidak berbeda nyata dengan ketiga sampel lainnya.

Penambahan ekstrak jahe 20\% pada edible film maizena secara nyata menurunkan kemampuan penghambatan susut berat sosis jika dibandingkan dengan kontrol. Hal ini disebabkan adanya pati yang masih terikut dalam ekstrak jahe. Paimin et al. (1991) menyatakan bahwa selain mengandung komponen minyak menguap (volatile oil) dan minyak tidak menguap (non-volatile oil), jahe juga mengandung pati. Pati merupakan material yang bersifat hidrofil, sehingga mudah dilewati oleh molekul air.

Jika dibandingkan dengan kontrol, susut berat edible coating sosis dengan penambahan ekstrak jahe $10 \%$ dan $30 \%$ tidak berbeda nyata, sedangkan susut berat edible coating sosis dengan penambahan ekstrak jahe 20\% berbeda nyata dan lebih tinggi. Dengan demikian, penambahan ekstrak jahe pada edible film maizena justru cenderung meningkatkan susut berat pada sosis. Hal ini disebabkan karena selain kehilangan air, juga akibat kehilangan minyak atsiri dalam edible coating sosis dengan penambahan ekstrak jahe. Kemampuan edible film maizena dengan penambahan ekstrak jahe tersebut juga masih jauh lebih rendah dibandingkan dengan edible film komposit glukomanan-maizena (Atmaja 2009) dalam menahan susut berat sosis selama penyimpanan. Seperti yang dilaporkan oleh Atmaja (2009), edible film komposit glukomananmaizena mampu menahan susut berat sosis selama penyimpanan hingga $0,06067 \mathrm{~g} / \mathrm{jam}$ dengan aplikasi sosis secara wrapping.

Tranggono dan Sutardi (1990) mengatakan bahwa derajat penurunan kecepatan kehilangan air tergantung pada permeabilitas kemasan terhadap transfer uap air serta kerapatan isi kemasan. Semua bahan yang biasa digunakan sebagai pengemas umumnya bersifat permeabel terhadap uap air hingga batas tertentu.

Krochta (1992) dalam Layuk (2001) menyebutkan bahwa edible film yang mempunyai sifat hidrofilik sangat peka terhadap penyerapan air. Oleh karena sifatnya hidrofilik, edible film tersebut sebaiknya digunakan sebagai pengemas primer, sehingga tidak terjadi kontak langsung dengan udara luar dan produk tidak cepat rusak.

\section{Uji kerusakan lemak}

Lemak hewan banyak mengandung asam lemak tidak jenuh, seperti asam oleat (18:1) sebesar 12,01\%, asam palmitoleat (16:1) sebesar $1,38 \%$, asam linoleat (18:2) sebesar 1,99\%, dan asam linolenat (18:3) sebesar 0,41\%. Asam-asam lemak tersebut dapat mengalami oksidasi, sehingga menimbulkan bau tengik pada daging. Hasil pemecahan dan oksidasi ikatan rangkap dari asam lemak tidak jenuh berupa asam lemak bebas yang merupakan sumber penyebab bau tengik. Kecepatan oksidasi berbanding lurus dengan tingkat ketidakjenuhan asam lemak. Asam linolenat dengan tiga ikatan rangkap lebih mudah teroksidasi daripada asam lemak linoleat dengan dua ikatan rangkap dan asam oleat dengan satu ikatan rangkap.

Proses oksidasi dapat berlangsung apabila terjadi kontak antara sejumlah oksigen dengan minyak atau lemak. Terjadinya reaksi oksidasi akan menimbulkan bau tengik pada minyak atau lemak (Ketaren 1986).

Frankel dalam Raharjo (2004) menyatakan bahwa laju oksidasi pada makanan dipengaruhi oleh sejumlah faktor, termasuk diantaranya suhu, inhibitor, katalisator, sifat dari lingkungan reaksi, dan sifat dari komponen yang terlibat. Asam lemak tidak jenuh dengan ikatan rangkap lebih dari satu lebih rentan terhadap oksidasi oksigen triplet yang dipicu oleh senyawa radikal dibandingkan asam lemak tidak jenuh dengan ikatan rangkap tunggal.

Sosis yang di-coating menggunakan edible film dengan penambahan variasi konsentrasi ekstrak jahe mengalami perlakuan penyimpanan selama 21 hari dan disimpan di dalam lemari pendingin dengan suhu $10^{\circ} \mathrm{C}$. Selanjutnya, pada sosis tersebut dilakukan pengujian terhadap kerusakan lemak yang meliputi uji Thiobarbituric Acid (TBA) dan uji asam lemak bebas.

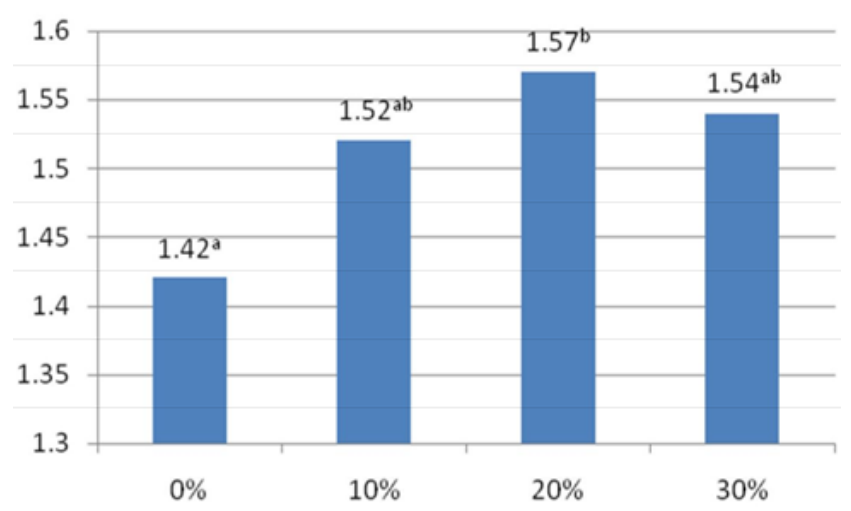

Gambar 1. Susut berat edible coating sosis. Angka yang diikuti dengan huruf/notasi yang sama menunjukkan tidak ada beda nyata 


\section{Uji TBA}

Uji TBA digunakan untuk mengetahui tingkat ketengikan pada lemak atau produk pangan berlemak. Lemak yang tengik mengandung aldehid dan sebagian besar berperan sebagai malonaldehid. Besarnya angka TBA berhubungan dengan ketengikan oksidatif pada bahan pangan. Menurut Syah (2005), ketengikan oksidatif terjadi jika sejumlah oksigen berhubungan dengan minyak/lemak. Molekul oksigen terikat pada ikatan ganda dari asam-asam lemak tidak jenuh. Ikatan ganda pada asam lemak tidak jenuh mengalami proses oksidasi yang selanjutnya akan dipecah dan membentuk asam lemak rantai pendek, aldehida, dan keton. Menurut Raharjo (2004), oksidasi lanjut pada aldehid tidak jenuh tersebut akan menghasilkan alhehid dan dialdehid dengan rantai pendek, termasuk malonaldehid.

Berdasarkan Tabel 2 dapat diketahui nilai TBA untuk masing-masing sampel dengan empat titik pengamatan tidak menunjukkan adanya beda nyata, kecuali untuk sampel dengan penambahan ekstrak jahe 30\% pada hari ke14 jika dibandingkan dengan kontrol, serta penyimpanan pada hari ke-21 jika dibandingkan dengan sampel dengan penambahan ekstrak jahe $10 \%$ dan 20\%. Penambahan ekstrak jahe $30 \%$ pada edible coating sosis memberikan pengaruh yang berbeda nyata pada penghambatan oksidasi asam lemak.

Angka TBA sosis yang di-coating menggunakan edible film dengan variasi konsentrasi ekstrak jahe pada penelitian ini meningkat dengan semakin lamanya waktu penyimpanan dan mulai menurun pada titik tertentu. Peningkatan angka TBA pada sampel dengan penambahan ekstrak jahe $0 \%, 10 \%$, dan 30\% tersebut diduga disebabkan oleh adanya oksidasi asam-asam lemak tidak jenuh pada sosis selama penyimpanan. Adapun terjadinya penurunan angka TBA pada sampel dengan penambahan ekstrak jahe $0 \%, 10 \%$, dan $30 \%$ setelah penyimpanan pada hari ke-7 diduga disebabkan oleh adanya reaksi aldehid dengan senyawa lain yang terdapat dalam sosis. Seperti yang dipaparkan oleh Gray (1987) dalam Raharjo (2004) bahwa nilai TBA yang rendah bukan selalu berarti lemak belum mengalami oksidasi, namun dapat terjadi karena aldehid yang terakumulasi sudah bereaksi dengan senyawa lain atau menguap selama penyimpanan.

Adapun peningkatan angka TBA pada hari ke-21 pada sampel dengan penambahan ekstrak jahe 30\% dapat disebabkan oleh oksidasi senyawa lain. Menurut Winarno (1992), dalam bahan pangan yang komposisinya cukup kompleks, ternyata hasil oksidasi yang terbentuk dapat mengoksidasi konstituen lain yang masih utuh dalam suatu bahan pangan.

Pada sampel dengan penambahan ekstrak jahe 20\% menunjukkan penurunan angka TBA. Hal ini menunjukkan adanya peran antioksidatif oleh senyawa yang terkandung dalam ekstrak jahe. Hal ini sebagaimana yang dilaporkan oleh Prangdimurti et al. (1999) dalam Zakaria et al. (2000) yang menyatakan bahwa di dalam jahe terkandung beberapa senyawa turunan fenol, antara lain gingerol, shogaol, dan senyawa-senyawa turunannya, yang mempunyai aktivitas antioksidan yang tinggi. Menurut Jadhav et al. (1996) dalam Dewi (2006), penambahan antioksidan ke dalam suatu bahan makanan yang mengandung lipid dapat meminimalkan ketengikan, mencegah pembentukan produk oksidasi yang bersifat tengik, dan mempertahankan kualitas nutrisi. Adanya antioksidan akan menghentikan reaksi oksidasi berantai.

Bentuk kerusakan, terutama ketengikan yang paling penting, dapat disebabkan oleh aksi oksigen udara terhadap lemak. Dekomposisi lemak oleh mikrobia hanya dapat terjadi jika terdapat air, senyawa nitrogen, dan garam mineral, sedangkan oksidasi oleh oksigen udara dapat terjadi secara spontan jika bahan yang mengandung lemak dibiarkan kontak dengan udara (Ketaren 1986).

Dengan adanya antioksidan maka reaksi oksidasi dapat dihambat, sehingga pembentukan senyawa aldehid, keton, dan asam lemak bebas, termasuk malonaldehid dapat dihambat. Menurut Ardiansyah (2007), antioksidan dapat memberikan atom hidrogen secara cepat ke senyawa radikal lipid dan mengubahnya ke bentuk yang lebih stabil, sehingga antioksidan dapat menghentikan reaksi berantai pada radikal bebas dari lemak yang teroksidasi. Beberapa komponen bioaktif dalam ekstrak jahe yang mempunyai aktivitas antioksidan antara lain (6)-gingerol, (6)-shogaol, dierilheptanoid, dan curcumin (Kikuzaki 1993 dalam Zakaria et al. 2000).

\section{Asam lemak bebas}

Asam lemak bebas tidak hanya terbentuk akibat proses hidrolisis saja, tetapi dapat juga terbentuk karena proses oksidasi sebagai akibat dekomposisi dari hidroperoksida. Sebagaimana dilaporkan oleh Ketaren (1986) bahwa oksidasi biasanya dimulai dengan pembentukan peroksida dan hidroperoksida. Tahap selanjutnya adanya terurainya asam-asam lemak disertai dengan konversi hidroperoksida menjadi aldehid, keton, serta asam-asam lemak bebas. Dengan adanya antioksidan, reaksi oksidasi dapat dihambat.

Dari Tabel 2 dapat diketahui bahwa nilai asam lemak bebas (ALB) untuk masing-masing sampel dengan empat titik pengamatan menunjukkan adanya beda nyata, kecuali untuk pengamatan pada hari ke-7. Adapun grafik hasil analisis TBA dapat dilihat pada Gambar 2.

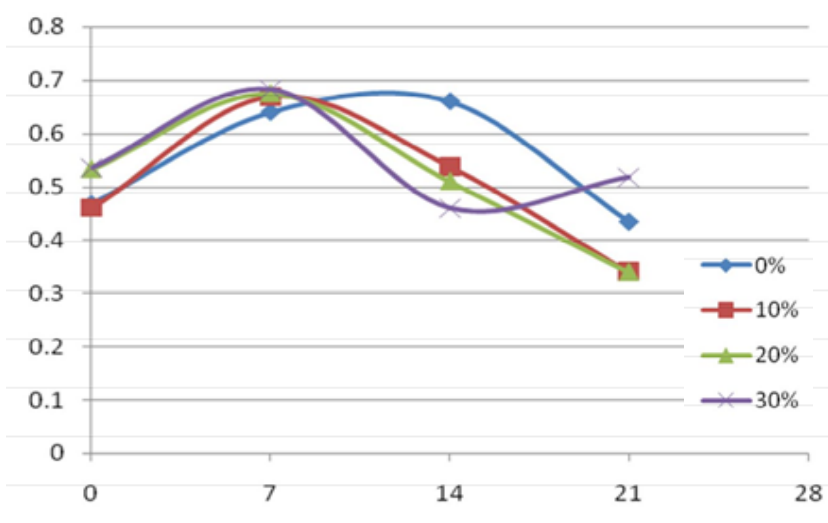

Gambar 2. Angka TBA pada sampel sosis yang di-coating menggunakan edible film dengan penambahan ekstrak jahe 
Dalam penelitian ini dilakukan uji asam lemak bebas pada sosis. Sosis mengandung lemak yang berbeda-beda dan kolesterol cukup tinggi (50-100 mg/100 gram), sehingga sangat mudah mengalami kerusakan, terutama kerusakan lemak akibat oksidasi.

Hasil pengujian angka asam lemak bebas pada sosis yang di-coating menggunakan edible film dengan variasi konsentrasi ekstrak jahe meningkat dengan semakin lamanya waktu penyimpanan. Hal ini menunjukkan peningkatan angka asam lemak bebas seiring bertambahnya waktu penyimpanan. Bilangan asam lemak bebas yang semakin tinggi mengindikasikan kerusakan minyak yang semakin tinggi. Selain itu, peningkatan angka asam lemak bebas tersebut juga dapat disebabkan oleh adanya aktivitas mikrobia pemecah lemak dalam bahan sosis.

Meskipun demikian, terjadi penurunan angka asam lemak bebas pada hari ke-21 untuk semua sampel. Hal ini diduga disebabkan asam-asam lemak bebas mengalami tahapan reaksi auto-oksidasi pada tahap terminasi, dimana asam lemak bebas terurai menjadi aldehid dan keton. Seperti yang dilaporkan oleh Ketaren (1986) bahwa oksidasi biasanya dimulai dengan pembentukan peroksida dan hidroperoksida. Tahap selanjutnya yaitu terurainya asam-asam lemak yang disertai dengan konversi hidroperoksida menjadi aldehid, keton, serta asam-asam lemak bebas.

Meskipun terjadi peningkatan kandungan asam lemak bebas selama penyimpanan, hasil pengujian angka asam lemak bebas pada sosis yang di-coating menggunakan edible film dengan penambahan variasi konsentrasi ekstrak jahe, masih lebih rendah dibandingkan dengan sosis yang di-coating dengan menggunakan edible film tanpa penambahan ekstrak jahe. Hal ini berarti penambahan ekstrak jahe mampu menurunkan tingkat kerusakan lemak ditinjau dari parameter kandungan asam lemak bebas. Hasil pengujian terhadap kandungan asam lemak bebas pada keempat sampel selama penyimpanan menunjukkan bahwa sampel dengan penambahan ekstrak jahe 10\% memiliki kemampuan paling baik yang ditunjukkan dengan peningkatan kandungan asam lemak bebas yang masih di bawah kandungan angka asam lemak bebas dari ketiga sampel lainnya (Gambar 2).

Menurut Ketaren (1986), beberapa jenis jamur, ragi, dan bakteri mampu menghidrolisis molekul lemak. Mikrobia yang sering terdapat pada produk pangan semibasah antara lain bakteri Staphylococcus, Lactobacillus, Micrococcus, dan bakteri halofilik. Jamur yang mampu menghirolisis lemak antara lain Aspergillus, Penicillium, Cladospora, dan beberapa jenis ragi seperti Saccharomyces, Candida, dan Pebaromyces. Hidrolisis lemak oleh mikrobia tersebut dapat berlangsung dalam kondisi aerob maupun anaerob. Bahan pangan berlemak dengan kadar air dan kelembapan udara tertentu merupakan medium yang baik bagi pertumbuhan jamur. Jamur tersebut mampu menghasilkan enzim, misalnya enzim lipase yang berfungsi untuk menguraikan trigliserida menjadi asam lemak bebas dan gliserol.

Dengan penambahan ekstrak jahe, pertumbuhan mikrobia dapat dihambat. Uhl (2000) menyatakan jahe seperti halnya dengan jenis rempah-rempah yang lain, memiliki kemampuan mempertahankan kualitas pangan yaitu sebagai antimikrobia dan antioksidan. Gingerone dan gingerol berperan dalam menghambat pertumbuhan bakteri Escherichia coli dan Bacillus subtilis, sedangkan kemampuan antioksidannya berasal dari kandungan gingerol dan shogaol.

\section{Karakteristik edible film maizena dengan penambahan ekstrak jahe}

Karakteristik edible film yang diuji adalah edible film terpilih dari uji aplikasi, yaitu edible film dengan penambahan ekstrak jahe sebesar $10 \%$ dengan edible film ekstrak jahe $0 \%$ sebagai kontrol. Adapun uji yang dilakukan adalah uji ketebalan, elongasi, tensile strength, tingkat kelarutan, dan WVP.

\section{Ketebalan film}

Ketebalan film merupakan parameter penting yang berpengaruh terhadap penggunaan film dalam pembuatan produk yang dikemasnya. Ketebalan film berpengaruh terhadap permeabilitas gas. Semakin tebal edible film maka permeabilitas gas akan semakin kecil dan melindungi produk yang dikemas dengan lebih baik. Ketebalan film juga dapat mempengaruhi sifat mekanik film yang lain, seperti tensille strength dan elongasi. Namun dalam penggunaannya, ketebalan edible film harus disesuaikan dengan produk yang dikemasnya (Kusumasmarawati 2007).

Hasil penelitian menunjukkan penambahan ekstrak jahe $10 \%$ cenderung menurunkan ketebalan edible film yang dihasilkan apabila dibandingkan dengan kontrol (edible film dengan penambahan ekstrak jahe $0 \%$ ), tetapi tidak berbeda nyata dengan kontrol. Ketebalan edible film maizena dengan penambahan ekstrak jahe ditunjukkan pada Gambar 3.

Dari hasil pengamatan yang dilakukan, edible film maizena dengan penambahan ekstrak jahe $10 \%$ mempunyai ketebalan 0,125 mm. Perbedaan ketebalan tersebut diduga disebabkan adanya pati yang terikut dalam ekstrak jahe, sehingga tebal film menjadi lebih padat jika dibandingkan dengan edible film kontrol.

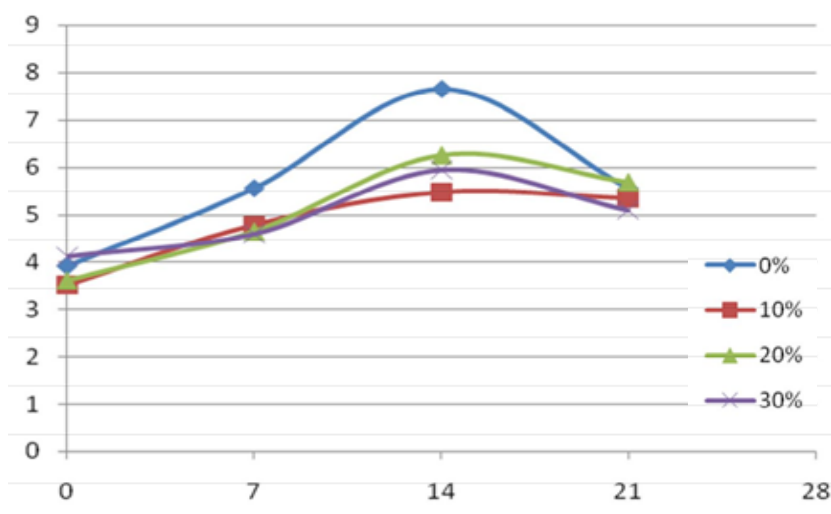

Gambar 3. Angka asam lemak bebas sampel sosis yang dicoating menggunakan edible film dengan penambahan ekstrak jahe 


\section{Kelarutan}

Kelarutan film merupakan faktor yang penting dalam menentukan biodegradibilitas film ketika digunakan sebagai pengemas. Terdapat film yang dikehendaki tingkat kelarutannya yang tinggi, atau sebaliknya tergantung jenis produk yang dikemas (Nurjannah 2004).

Dari Tabel 3 dapat diketahui bahwa edible film maizena dengan penambahan ekstrak jahe sebesar $10 \%$ memiliki kelarutan yang lebih tinggi dan berbeda nyata jika dibandingkan dengan edible film dengan penambahan ekstrak jahe 0\%. Penambahan ekstrak jahe secara nyata mampu meningkatkan tingkat kelarutan film. Hal ini terlihat dari edible film dengan penambahan ekstrak jahe 0\% yang memiliki tingkat kelarutan yang lebih rendah. Adanya penambahan ekstrak jahe diduga mampu meningkatkan kelarutan film. Film yang terbuat dari pati cenderung bersifat hidrofilik, sehingga mudah larut dalam air. Penambahan ekstrak jahe mampu meningkatkan kelarutan film, hal itu disebabkan ekstrak jahe masih mengandung pati.

Siswanti (2008) menunjukkan hasil yang serupa, yaitu edible film komposit glukomanan-maizena dengan konsentrasi glukomanan $15 \%$ dan ketebalannya 0,1828 $\mathrm{mm}$, memiliki tingkat kelarutan yang lebih tinggi daripada konsentrasi glukomanan 0\% dengan ketebalan 0,1613 mm. Menurut Rokhaniah (2003), suhu juga mempengaruhi kelarutan film. Beberapa molekul tidak larut dalam air dingin, namun dengan semakin meningkatnya suhu akan mengalami pelelehan (chain melting) yang memungkinkan terpenetrasinya air ke bagian yang bersifat hidrofilik.

\section{Tensile strength}

Hasil pengujian terhadap kekuatan regang putus edible film maizena dengan penambahan ekstrak jahe ditunjukkan pada Tabel 3. Dari tabel tersebut dapat diketahui bahwa penambahan ekstrak jahe cenderung menurunkan kekuatan regang putus (tensile strength) edible film yang dihasilkan. Namun berdasarkan hasil uji statistik, tidak terdapat perbedaan kekuatan regang putus yang signifikan antar kedua jenis edible film. Hal ini menunjukkan bahwa penambahan konsentrasi ekstrak jahe $10 \%$ tidak berpengaruh nyata terhadap kekuatan regang putus edible film yang dihasilkan.

Jika dibandingkan dengan edible film komposit maizena-glukomanan, edible film maizena dengan penambahan ekstrak jahe memiliki nilai tensile strength yang lebih besar. Manuhara (2003) menyebutkan biasanya sifat mekanik film tergantung pada kekuatan bahan yang digunakan dalam pembuatan film untuk membentuk ikatan molekuler dalam jumlah yang banyak dan kuat.

Menurut Wu dan Bates (1973), edible film dengan kekuatan tarik yang tinggi mampu melindungi produk yang dikemasnya dari ganggunan mekanis dengan baik, sedangkan kekuatan tarik film dipengaruhi oleh formulasi bahan yang digunakan.

\section{Elongasi}

Elongasi atau pemanjangan didefinisikan sebagai persentase perubahan panjang film pada saat film ditarik sampai putus (Krochta dan de Mulder-Johnston 1997).
Elongasi dari edible film yang dihasilkan dalam penelitian ini dapat dilihat pada Tabel 3. Penambahan eksrak jahe cenderung menurunkan elongasi pada edible film yang dihasilkan. Penurunan elongasi tersebut diduga terjadi karena adanya kandungan pati yang masih terikut di dalam ekstrak jahe. Adanya pati menambah padatan dalam film yang menyebabkan film menjadi kuat namun kurang elastis, sehingga elongasi menurun. Akan tetapi dari hasil uji statistik, penurunan tersebut tidak memberikan nilai yang berbeda nyata terhadap edible film tanpa penambahan ekstrak jahe.

Tabel 1. Data skor pengujian organoleptik edible coating sosis

\begin{tabular}{lccccc}
\hline $\begin{array}{l}\text { Konsentrasi } \\
\text { ekstrak } \\
\text { jahe }\end{array}$ & Aroma & Rasa & Aftertaste & Kekenyalan Keseluruhan \\
\hline $0 \%$ & $4,1^{\mathrm{a}}$ & $4,0^{\mathrm{a}}$ & $3,7^{\mathrm{b}}$ & $3,8^{\mathrm{a}}$ & $4,1^{\mathrm{b}}$ \\
$10 \%$ & $3,6^{\mathrm{a}}$ & $3,8^{\mathrm{a}}$ & $3,4^{\mathrm{ab}}$ & $3,7^{\mathrm{a}}$ & $3,9^{\mathrm{b}}$ \\
$20 \%$ & $3,6^{\mathrm{a}}$ & $3,5^{\mathrm{a}}$ & $2,8^{\mathrm{a}}$ & $3,4^{\mathrm{a}}$ & $3,3^{\mathrm{a}}$ \\
$30 \%$ & $3,8^{\mathrm{a}}$ & $3,5^{\mathrm{a}}$ & $2,9^{\mathrm{a}}$ & $3,6^{\mathrm{a}}$ & $3,2^{\mathrm{a}}$ \\
\hline
\end{tabular}

Keterangan: Angka dengan notasi yang sama berarti tidak beda nyata pada tingkat kepercayaan $95 \%$. Skala nilai: (1) tidak suka, (2) kurang suka, (3) netral, (4) suka, (5) sangat suka

Tabel 2. Pengujian kerusakan oksidatif lemak pada sosis dengan pengujian TBA dan ALB

\begin{tabular}{llllll}
\hline $\begin{array}{l}\text { Jenis } \\
\text { uji }\end{array}$ & $\begin{array}{l}\text { Konsentrasi } \\
\text { ekstrak jahe }\end{array}$ & Hari ke-0 & \multicolumn{2}{l}{ Hari ke-7 Hari ke-14 } & Hari ke-21 \\
\hline \multirow{4}{*}{ TBA } & $0 \%$ & $0,468^{\mathrm{a}}$ & $0,640^{\mathrm{a}}$ & $0,660^{\mathrm{b}}$ & $0,435^{\mathrm{ab}}$ \\
& $10 \%$ & $0,460^{\mathrm{a}}$ & $0,670^{\mathrm{a}}$ & $0,538^{\mathrm{ab}}$ & $0,340^{\mathrm{a}}$ \\
& $20 \%$ & $0,533^{\mathrm{a}}$ & $0,675^{\mathrm{a}}$ & $0,510^{\mathrm{ab}}$ & $0,340^{\mathrm{a}}$ \\
& $30 \%$ & $0,535^{\mathrm{a}}$ & $0,682^{\mathrm{a}}$ & $0,460^{\mathrm{a}}$ & $0,518^{\mathrm{b}}$ \\
& $0 \%$ & $3,92^{\mathrm{ab}}$ & $5,56^{\mathrm{a}}$ & $7,65^{\mathrm{b}}$ & $5,56^{\mathrm{b}}$ \\
\multirow{2}{*}{ ALB } & $10 \%$ & $3,52^{\mathrm{a}}$ & $4,79^{\mathrm{a}}$ & $5,48^{\mathrm{a}}$ & $5,35^{\mathrm{ab}}$ \\
& $20 \%$ & $3,61^{\mathrm{a}}$ & $4,65^{\mathrm{a}}$ & $6,26^{\mathrm{ab}}$ & $5,69^{\mathrm{b}}$ \\
& $30 \%$ & $4,11^{\mathrm{b}}$ & $4,59^{\mathrm{a}}$ & $5,95^{\mathrm{ab}}$ & $5,09^{\mathrm{a}}$ \\
\hline
\end{tabular}

Keterangan: Angka yang diikuti dengan huruf/notasi yang sama menunjukkan tidak ada beda nyata untuk kolom yang sama serta parameter uji yang sama.

Tabel 3. Hasil uji karakteristik fisik dan mekanik pada edible film maizena dengan penambahan ekstrak jahe $10 \%$

\begin{tabular}{lccccc}
$\begin{array}{l}\text { Konsentrasi } \\
\text { ekstrak jahe }\end{array}$ & (g.mm & Elongasi & Tensile & \multicolumn{2}{c}{ Ketebalan Kelarutan } \\
$(\mathbf{N})$ & Strength $(\mathbf{N})$ & $(\mathbf{m m})$ & $(\%)$ \\
\hline $0 \%$ & $6,847^{\mathrm{a}}$ & $18,77^{\mathrm{a}}$ & $2,039^{\mathrm{a}}$ & $0,135^{\mathrm{a}}$ & $16,45^{\mathrm{a}}$ \\
$10 \%$ & $6,664^{\mathrm{a}}$ & $13,99^{\mathrm{a}}$ & $1,455^{\mathrm{a}}$ & $0,125^{\mathrm{a}}$ & $29,27^{\mathrm{b}}$ \\
\hline
\end{tabular}


Pada umumnya, film yang terbuat dari pati mudah rusak. Peningkatan konsentrasi bahan akan menyebabkan peningkatan matrik yang terbentuk, sehingga film akan manjadi kuat. Namun, peningkatan konsentrasi bahan juga dapat menyebabkan penurunan rasio gliserol sebagai plasticizer terhadap pati, sehingga mengakibatkan penurunan elongasi film apabila terkena gaya, yang selanjutnya akan menyebabkan film mudah patah (Barus 2002). Krochta dan de Mulder-Johnston (1997) menyebutkan persentase elongasi pada edible film dikatakan baik jika nilainya lebih dari $50 \%$ dan dikatakan jelek jika nilainya kurang dari $10 \%$. Nilai elongasi edible film maizena dengan penambahan ekstrak jahe berkisar antara $13,99-18,77 \%$.

\section{WVP}

Pengujian WVP digunakan untuk mengukur kemampuan edible film dalam menahan migrasi uap air. Menurut Gontard et al. (1993), salah satu fungsi edible film adalah untuk menahan migrasi uap. Winarno (1997) menyebutkan bahwa dengan adanya air, lemak dapat terhidrolisis menjadi gliserol dan asam lemak. Dengan adanya edible coating pada sosis diharapkan mampu menahan migrasi uap air dari produk ke lingkungan, ataupun sebaliknya, dari lingkungan ke produk.

Hasil pengujian terhadap permeabilitas uap air pada edible film maizena dengan penambahan ekstrak jahe ditunjukkan pada Tabel 3. Dari tabel tersebut dapat diketahui bahwa penambahan ekstrak jahe sebesar $10 \%$ pada edible film maizena cenderung menurunkan permeabilitas uap air edible film, akan tetapi tetap tidak memberikan pengaruh yang berbeda nyata antar keduanya. Hal itu diduga karena dalam ekstrak jahe masih mengandung pati yang dapat menambah matriks dalam film. Selain itu, penggunaan maizena sebagai bahan pembuatan edible film diduga mampu menurunkan permeabilitas uap air dari film yang dihasilkan.

Hal ini disebabkan karena zein dalam maizena memiliki keunikan yaitu mempunyai komposisi asam amino penyusun yang sebagian besar berupa asam amino nonpolar, seperti leusin, prolin, dan alanin (Shewry dan Miflin 1985). Dalam air, bagian hidrofobik dari asam-asam amino tersebut cenderung untuk berikatan satu dengan lainnya (Wall dan Paulis 1978 dalam Krochta et al. 1994).

\section{KESIMPULAN}

Penambahan ekstrak jahe pada pembuatan edible coating sosis tidak berpengaruh nyata terhadap tingkat kesukaan panelis, kecuali pada parameter aftertaste dan keseluruhan. Penambahan ekstrak jahe pada pembuatan edible coating sosis yang paling disukai secara keseluruhan oleh panelis adalah konsentrasi $10 \%$. Penghambatan susut berat paling baik pada edible coating sosis yang ditambah dengan ekstrak jahe ditunjukkan oleh sampel dengan konsentrasi penambahan ekstrak jahe $10 \%$. Angka TBA sosis yang di-coating menggunakan edible film dengan variasi konsentrasi ekstrak jahe meningkat dengan semakin lamanya waktu penyimpanan dan mulai menurun pada titik tertentu. Penambahan ekstrak jahe pada edible coating sosis menurunkan tingkat kerusakan oksidatif lemak sosis ditinjau dari uji TBA jika dibandingkan kontrol, kecuali sampel dengan penambahan ekstrak jahe $30 \%$ pada hari ke-21. Penambahan ekstrak jahe pada edible coating sosis menurunkan nilai angka asam lemak bebas pada sosis jika dibandingkan dengan kontrol. Hal ini berarti penambahan ekstrak jahe menurunkan kerusakan oksidatif lemak. Penambahan ekstrak jahe pada pembuatan edible film yang menunjukkan tingkat kerusakan oksidatif lemak paling kecil dari uji TBA dan ALB selama penyimpanan adalah konsentrasi 10\%. Penambahan ekstrak jahe $10 \%$ pada pembuatan edible film tidak berpengaruh nyata terhadap WVP, elongasi, tensile strength, dan ketebalan, akan tetapi meningkatkan kelarutan secara nyata.

\section{DAFTAR PUSTAKA}

Aminah S. 1992. Kajian Pembentukan Gel Glukomanan dari Umbi Ilesiles (Amorphopallus oncophylus Pr.) Hasil Pengendapan Glukomanan dengan Menggunakan Alkohol. [Skripsi]. Fakultas Teknologi Pertanian, UGM, Yogyakarta.

Ardiansyah. 2007. Antioksidan dan peranannya bagi kesehatan. www.chaptereislamicspace.wordpress.com. [7 Maret 2009].

Astawan M. 2008. Bahaya laten sepotong sosis. http://dinimantap.multiply.com/. [7 Maret 2009].

Atmaja. 2009. Karakterisasi edible film dari tepung komposit glukomanan maizena dan aplikasinya pada pengemasan sosis. Program Kegiatan Mahasiswa. Teknologi Hasil Pertanian. Universitas Sebelas Maret, Surakarta.

Barus SP. 2002. Karakteristik Film Pati Biji Nangka (Artocarpus integra Meur) dengan Penambahan CMC. [Skripsi]. Universitas Atma Jaya, Yogyakarta.

Darmadji P. 2002. Aplikasi "Response Surface Methodology" untuk optimasi proses dengan parameter sensoris. Seminar PATPI. Malang.

De Man JM. 1976. Priciples of food chemistry. The AVI Publishing Co. Inc., Westport Co.

Dewi KYS. 2006. Identifikasi dan Karakterisasi Antioksidan dalam Jus Aloe chinensis dan Evaluasi Potensi Aloe-Emodin sebagai Antifotoksidan dalam Sistem Asam Linoleat. [Disertasi]. Universitas Gadjah Mada, Yogyakarta.

Gontard N, Guilbert S, Cuq JL. 1993. Water and glyserol as plasticizer afect mechanical and water barrier properties of an edible wheat gluten film. J Food Sci 58(1): 206-211.

Guilbert S. 1988. Use of superficial edible layer to protect intermadiet mouister food: Application to the protection of tropical fruit dehydrated by osmosis. In: Seow BC (ed). Food Preservation by Mouister Control. Elsevier Applied Science Publisher, London, UK.

Hasyim N. 2008. Kajian Kerusakan Minyak pada "Jenang Kudus" dengan Penambahan Ekstrak Jahe (Zingiber officinale Roscoe) Selama Penyimpananan. [Skripsi]. Fakultas Pertanian, UNS, Surakarta.

Ketaren S. 1986. Pengantar teknologi minyak dan lemak pangan. UI Press, Jakarta.

Krochta JM, de Mulder-Johnston. 1997. Edible and biodegradable polymers Film: Challenges and opportunities. Food Technol 51: 6174.

Krochta JM, Baldwin EA, Nisperos-Carriedo MO. 1994. Edible coatings and films to improve food quality. Technomis Publishing Co, Inc. Lancester, Bosel.

Kusumasmarawati AD. 2007. Pembuatan Pati Garut Butirat dan Aplikasinya dalam Pembuatan Edible Film. [Tesis]. Program Pascasarjana, UGM, Yogyakarta.

Larmond E. 1977. Laboratory methods of sensory evaluation of foods. Dept Agri Ottawa, Canada.

Layuk P. 2001. Karakterisasi Edible Film Komposit Pektin Daging Buah Pala dan Tapioka. [Tesis]. Program Pascasarjana, UGM, Yogyakarta. 
Manuhara GJ. 2003. Ekstraksi Karaginan dari Rumput Laut Eucheuma sp. untuk Pembuatan Edible film. [Skripsi]. Fakultas Teknologi Pertanian UGM, Yogyakarta.

McHugh TH, Krochta JM. 1994. Sorbitol vs gliserol plasticized whey protein edible film: Integrated oxygen permeability and tensile strength evaluation. J Agric Food Chem 42(4): 841-845.

McHugh TH, Sanesi E. 2000. Apple wrops: A novel method to improve the quality and extend the shelf life of fresh-cut apples. J Food Sci 56(3): 480-485

Nakatani N. 1992. Natural antioxidants from spices. In: Huang MT, Ho CT, Lee CY (eds). Phenolic Compounds in Food and Their Effects on Health. American Society, Washington DC.

Nurjannah W. 2004. Isolasi dan Karakterisasi Alginat dari Rumput Lau Sargassum sp. untuk Pembuatan Biodegradable Film Komposit Alginat Tapioka. [Skripsi]. Fakultas Teknologi Pertanian, UGM, Yogyakarta.

Paimin, Farry B, Murhananto. 1991. Budi Daya, Pengolahan, Perdagangan. Penebar Swadaya, Jakarta.

Phillips GO, Williams PA. 2000. Starch. In: Handbook of Hydrocolloids. CRC Press, Cambridge, London.

Pomes AF. 1971. Zein. In: Mark HF, Gaylord NG, Bikales NM (eds) Encyclopedia of Polymer Science and Technology: Plastics, Resins, Rubbers, Fibers. Volume 15. Interscience Publishers, New York.

Raharjo Sri. 2004. Kerusakan oksidatif pada makanan. Pusat Studi Pangan dan Gizi, UGM, Yogyakarta.

Riadi TJH. 2007. Biodegradable plastik pembungkus yang bisa dimakan. www.pikiranrakyat.com. [7 Maret 2009].

Rokhaniah. 2003. Isolasi dan Karakterisasi Pati Biji Nangka (Artocorpus heterophyllus Lamk) untuk Pembuatan Biodegradable Film. [Skripsi] Fakultas Teknologi Pertanian, UGM, Yogyakarta
Sherwin ER. 1990. Antioxidants. In: Brannen AL, Davidson PM, Salminen S (eds). Food Additives. Marcell Dekker, Inc., New York

Shewry PR, Miflin BJ. 1985. Seed storage proteins of economically important cereals in advances in cereal science and technology, Volume 7. In: Pomeranz Y (ed). American Association of Cereal Chemists. Inc., St. Paul.

Siswanti. 2008. Karakterisasi Edible Film Komposit dari Glukomanan Umbi Iles-iles (Amorphopallus muelleri Blume) dan Maizena. [Skripsi]. Fakultas Pertanian, UNS, Surakarta.

Suratmo Y. 2008. Hati-hati makan sosis. www.kabarinews.com. [7 Maret 2009].

Suryaningrum DTH, Basmal J, Nurochmawati. 2005. Studi pembuatan edible film dari karaginan. Jurnal Penelitian Perikanan Indonesia 11(4): 1-13.

Syah ANA. 2005. Virgin Coconut Oil minyak penakluk aneka penyakit. PT. AgroMedia Pustaka, Depok.

Tranggono, Sutardi. 1990. Biokimia dan teknologi pascapanen. Pusat Antar Universitas Pangan dan Gizi, UGM, Yogyakarta

Uhl SR. 2000. Handbook of spices, seasonings and flavoring. Technomic Publishing Co. Inc., Lancaster-USA.

Winarno FG. 1992. Kimia pangan dan gizi. PT Gramedia Pustaka Utama, Jakarta.

Wu LC, Bates RP. 1973. Soy protein-lipid films: optimation of film formation. J Food Sci 37: 40-44.

Zakaria FR, Susanto H, Hartoyo A. 2000. Pengaruh konsumsi jahe (Zingiber officinale Roscoe) terhadap kadar malonaldehida dan vitamin E plasma pada mahasiswa pesantren Ulil Albaab Kedung Badak, Bogor. Buletin Teknologi dan Industri Pangan 11(1): 36-40. 